\title{
RAFAŁ DROZDOWSKI
}

\section{UNIERUCHAMIAJĄCA MOC BAZ DANYCH}

\begin{abstract}
Drozdowski Rafał, Unieruchamiajaca moc baz danych [Immobilizing power of databases] edited by M. Krajewski - „Człowiek i Społeczeństwo”, vol. XXXVI, iss. 2, Poznań 2013, pp. 315-325. Adam Mickiewicz University Press. ISBN 978-83-232-2672-7. ISSN 0239-3271.

Digital databases democratizes access to information and start a whole new set of social relations. On the other hand, the gigantism of digital databases disincentive to engage in their replenishment and hinders the use of their resources. This article is an attempt to answer the question of what features of modern databases and the management rules increase the chance of them activating and ties making potential.
\end{abstract}

Rafał Drozdowski, Uniwersytet im. Adama Mickiewicza w Poznaniu, Instytut Socjologii, ul. Szamarzewskiego 89c, 60-569 Poznań, Poland.

\section{UWAGI WSTĘPNE}

$\mathrm{W}$ niniejszym artykule chcę się zastanowić nad jednym $\mathrm{z}$ „ukrytych programów" (wizualnych, ale chyba nie tylko wizualnych) baz danych, jakim są ich (potencjalnie) unieruchamiajace konsekwencje. To oczywiście prawda, że bazy danych uruchamiają określone procesy, że aktywizują i pobudzają oraz że można o nich z sensem i przekonująco mówić z perspektywy performatyki ${ }^{1}$. To prawda więc, że bazy danych "wprawiają w ruch społeczeństwo", sprawiają, że "gęstnieje" ono i intensyfikuje się $\mathrm{w}$ swoim sprawstwie. Działania podejmowane wobec i pod wptywem baz danych siłą rzeczy prowokują do refleksyjnienia wielu niezatrzymujących dotąd uwagi problemów, siłą rzeczy generują nowe interakcje i nowe relacje społeczne, siłą rzeczy implikują nowe przepływy informacji. Prawdą jest jednak i to, że nowoczesne bazy danych również unieruchamiają.

${ }^{1}$ Zob. artykuł Marka Krajewskiego Performatywność baz danych na przykładzie bazy danych wizualnych "Niewidzialne miasto" zawarty w niniejszym tomie. 
Być może owe sugerowane tu przeze mnie unieruchamiające konsekwencje baz danych powinno się rozumieć tylko jako ich preformatywność ${ }^{2}$. Innymi słowy, niewykluczone, że wiele (większość) baz danych wprawdzie wywołuje działania, lecz tylko takie, które koniec końców powstrzymują zmiany i niczego nie przewracając do góry nogami, jedynie reprodukują czy legitymizują zastany porządek rzeczy. Być może jest jednak znacznie gorzej: wyobrażam sobie, iż w wielu okolicznościach wszyte w bazy danych "logiki” i „racjonalności” skutkują ich antyperformatywnościa.

Bezpośrednim tłem rozważań i opinii zamkniętych w ramy tego opracowania jest projekt „Niewidzialne miasto"3. Może on być postrzegany jako poligon doświadczalny, który pomógł naukowo urefleksyjnić nie tylko fenomen niezalegitymizowanych i niewspieranych systemowo praktyk miejskich, lecz także mnóstwo szans i pułapek, zysków i kosztów, nadziei i dylematów, jakie niesie z sobą praca badawcza polegająca na konstruowaniu i wykorzystywaniu (wizualnej) bazy danych.

Szczególne znaczenie, jakie przywiązywaliśmy - jako realizatorzy „Niewidzialnego miasta" - do bazy zdjęciowej, brało się oczywiście stąd, że była ona zaczynem i rdzeniem całego projektu. Nie powinno więc dziwić i to, iż byliśmy specjalnie wyczuleni na wszystkie kwestie dotyczące postępowania $\mathrm{z}$ „naszą" bazą.

Niniejszy tekst żywi się raczej wątpliwościami, jakie pojawiały się w toku naszych dyskusji na temat bazy wizualnej "Niewidzialne miasto” (odnoszącymi się do tego, jak ją rozwijać, jak interpretować, jak udostępniać, jak nią zarządzać itd.). Wątpliwości te łatwo uznać za coś, co przemawia przeciwko zrealizowanemu projektowi. W rzeczywistości jednak brały się one z naszej ostrożności metodologicznej, której rezultatem - siłą rzeczy - musiał być szybszy przyrost pytań niż odpowiedzi.

\section{PIĘĆ POWODÓW DO NIEPOKOJU}

Dla inicjatorów premia za pierwszeństwo. Reszta przychodzi na gotowe. Na początek uwaga zapewne najbardziej spodziewana. Nie sposób nie zgodzić się z tym, że nowoczesne bazy danych przypominają zaprogramowane aparaty (fotograficzne), o których pisał już jakiś czas temu

2 Odwołuję się tu do określenia Jonasa Larsena - zob. J. Larsen, Z rodzina najlepiej wychodzi się na zdjęciach: performatywność fotografii turystycznej, [w:] Badania wizualne w działaniu. Antologia tekstów, red. M. Frąckowiak, K. Olechnicki, Warszawa 2011.

3 Więcej o projekcie "Niewidzialne miasto" zob. na stronie www.niewidzialnemiasto.pl [dostęp: 20.11.2012]. Na temat historii i założeń projektu zob. też M. Krajewski, (Nie)widzialne miasto. Wstęp, [w:] niewidzialne miasto \#1. poznań, Poznań 2007, oraz blog poświęcony projektowi: http://nmbadania.info [dostęp: 20.11.2012]. 
Vilém Flusser4. Podobnie więc jak istnieje coś takiego jak program aparatu fotograficznego (dość skutecznie, co można zaobserwować, zachęcający do ściśle określonych stylów i sposobów fotografowania i równie skutecznie zniechęcajacy do eksperymentowania z kamerą i z obrazem), istnieje również coś takiego jak program bazy danych. Można rozumieć pod tym pojęciem na przykład reguły dostępowe do bazy, zasady administrowania jej treścią i oczywiście jej architekturę. „Niewidzialne miasto” pojęte jako baza danych wizualnych miało i ma swój "regulamin” (skądinąd bardzo otwarty, zachęcający i nieopresyjny5). Stworzonej na potrzeby projektu bazie nadano czytelną strukturę opartą na szesnastu kategoriach (Agory i kluby, Bezpieczeństwo, Miejsca dziecięce, Protezy instytucji, Upiększenia itd.). Od początku było wiadomo, że ów katalog form i przejawów „niewidzialnego miasta” nie jest wyczerpujący. Można by go uszczegóławiać (np. dzieląc Agory i kluby na prywatne i publiczne, prowizoryczne i noszące znamiona trwałości, legalne i nielegalne itd.) lub rozbudowywać wszerz, dodając dziesiątki nowych kategorii (np. Miejsca starych ludzi, Miejsca poczekalnie). Od początku przyjmowaliśmy również, że zaproponowane przez nas kategorie „niewidzialnego miasta" tworzą katalog półotwarty, że innymi słowy, nie jest z góry przesądzone, czy struktura stworzonej na potrzeby projektu bazy danych przetrwa - w niezmienionej postaci - do momentu jego zamknięcia, czy też będzie ewoluować.

Problem w tym, że nacisków, by wydyskutowaną w wąskim gronie inicjatorów projektu strukturę bazy zdjęć dokumentujących „niewidzialne miasto" poddawać jakimś modyfikacjom, by coś z niej usuwać bądź coś do niej dodawać, właściwie nie było. Można więc powiedzieć, że osoby, które dołączały - jako fotografujący - do projektu, w miarę jak poszerzał on swój geograficzny zasięg6, po prostu przyjęły do wiadomości ustalone „reguły gry" (rozumiane jako sposób mapowania „niewidzialnego miasta”, jako sposób rozumienia, czym jest i czym nie jest "niewidzialne miasto”, jako sposób kategoryzowania jego przejawów itd.). Nawiązując do Larsena, zaangażowanie tych osób miało charakter już tylko preformatywny: potwierdzało pierwotny zbiór założeń, rozstrzygnięć, prekwalifikacji i pretypologizacji,

${ }^{4}$ Zob. V. Flusser, Ku filozofii fotografii, Katowice 2004.

${ }^{5}$ Zob. zakładka „O projekcie”, www.niewidzialnemiasto.pl.

${ }^{6}$ Projekt rozpoczął się w Poznaniu, natomiast w krótkim czasie objął także inne miasta, m.in. Bydgoszcz, Chorzów, Katowice, Kraków, Łódź, Tarnów, Toruń, Wrocław, Warszawę i Zieloną Górę. Zasadniczą część zdjęć zgromadzonych w bazie wykonali socjolodzy, antropolodzy i kulturoznawcy, ściśle współpracujący z poznańskimi koordynatorami projektu jako jego „podwykonawcy” w poszczególnych miastach. Swoje zdjęcia do bazy „Niewidzialne miasto" mógł i może nadsyłać jednak każdy. Z możliwości tej skorzystało jak dotąd około trzystu osób. 
czyniąc ich ewentualną rewizję coraz bardziej niemożliwą i coraz bardziej nie-do-pomyślenia.

Uwidzialnione problemy znikają z oczu. Głęboko wierzę, że wiele dobrze pomyślanych, angażujących baz danych ma / może mieć ogromną moc sprawczą. Dotyczy to z pewnością zwłaszcza tych spośród nich, które zostały wymyślone i są rozwijane jako swoiste bazy-dowody rzeczowe i bazy-świadectwa (złych praktyk władzy, przejawów dyskryminacji i przemocy lub choćby tylko przejawów codziennej bezmyślności, codziennego braku wyobraźni ${ }^{7}$ ). Wiele podobnych baz wymusza swoim istnieniem pewne kroki prawne, mobilizuje opinię publiczną, przekształca pierwotne misje określonych instytucji, stawia pod ścianą wskazanych decydentów, zmuszając ich do ustępstw, itd.

Obawiam się jednak, że ma tu miejsce także inny mechanizm, na który już dość dawno zwróciliśmy uwagę z Markiem Krajewskim, pisząc wspólnie o dylematach i pułapkach raczkującej wówczas - przynajmniej w Polsce reklamy społecznej ${ }^{8}$. Otóż stwierdziliśmy wtedy, iż poruszenie w kampanii społecznej jakiejś kwestii, jakiejś ważnej i doniosłej społecznie „sprawy do załatwienia", jakiegoś palącego problemu, w paradoksalny sposób powoduje swoiście magiczne przekonanie, że problem ten już jest rozwiazywany lub że już zostat rozwiazany. Skonstatowanie, iż ktoś się czymś zainteresowat i zająt, budzi przeświadczenie, że skoro tak, to wszystko jest na jak najlepszej drodze i nikt $\mathrm{z}$ nas już się wtaściwie nie musi tym czymś interesować ani zajmować.

Wydaje się, że w przypadku wielu baz danych, które pomyślane zostały jako bazy performatywne lub uperformatywniające, sprawa przedstawia się bardzo podobnie. Samo ich istnienie, sam fakt, iż ktoś powołał je do życia, łącząc z nimi określone ważne cele społeczne lub polityczne, może być odczytywany jako „załatwienie sprawy", jako uspokajający sygnał, że taka czy inna kwestia jest zauważona, że stworzono mechanizm nacisku społecznego, dzięki któremu "stosowne instytucje podejmą stosowne kroki”, że wreszcie społeczna widzialność problemu - skoro już o nią zadbano - niejako automatycznie pociągnie za sobą jego społeczne urefleksyjnienie.

\footnotetext{
${ }^{7}$ Wydaje się, że cechy te spełniają dziś w największym stopniu portale - bazy danych zakładane przez organizacje strażnicze i przez dziennikarzy-obywateli. Więcej na temat obu tych - skądinąd ściśle ze sobą powiązanych - zjawisk zob. R. Drozdowski, Dziennikarstwo obywatelskie - próba socjologicznego opisu, "Ruch Prawniczy, Ekonomiczny i Socjologiczny” 2008, z. 3. W jakimś stopniu spełniają je jednak również komercyjne i czysto rozrywkowe przedsięwzięcia, takie jak np. Demotywatory.pl.

8 Zob. R. Drozdowski, M. Krajewski, Reklama społeczna w Polsce. Grzechy i możliwości, [w:] Akademia Europejska - materiaty szkoleniowe, Bielsko-Biała 1998; artykuł ten dostępny jest również na stronie internetowej Fundacji Komunikacji Społecznej: http://www.fks.org.pl/ b-art-reklama.php [dostęp: 23.11.2012].
} 
Wyobrażam sobie (niestety), że również zdjęcia dokumentujące "niewidzialne miasto" (oglądane oczyma kogoś kibicującego słabszej stronie rozmaitych gier i walk o miasto, o prawo do miasta i o prawo do bycia w mieście na własnych warunkach) mogą w ostatecznym rozrachunku działać jako przedwczesne uspokojenia. Zdjęcia te uspokajają, bo można je odczytywać jako świadectwa, że stabsza strona radzi sobie całkiem dobrze, nadspodziewanie dobrze, że może nawet zawłaszcza ona przestrzeń miejską skuteczniej i bardziej bezwzględnie, niż byśmy się tego po niej spodziewali. Gorzej, że to uspokojenie chwilę później unieruchamia. Skoro stabi radzą sobie tak dobrze, nie trzeba już zastanawiać się nad tym, czy i jak ich ewentualnie wesprzeć. Skoro słabi nie są aż tak słabi, jak się nam pierwotnie zdawało, mamy ich poniekąd "z głowy”, wolno nam przestać o nich rozmyślać jako o kimś, kto (ewentualnie) czeka na jakiś, choćby symboliczny, gest poparcia $\mathrm{z}$ naszej strony.

Paradoksalnie, baza zdjęć „Niewidzialne miasto” unieruchamia (dodać można: tym razem na szczęście) także tych, którzy oglądają ją bez życzliwości - traktując jej zawartość jako swoisty „zbiór donosów” na władze miejskie nieumiejące zaplanować przestrzeni miejskiej, nieumiejące zdyscyplinować „żywiołowego miasta” i nieumiejące zorganizować efektywnego nadzoru nad miastem. Skoro bowiem wszystkie te mniej lub bardziej malownicze, ale też irytujące, np. z perspektywy biurka miejskiego konserwatora, szefa straży miejskiej czy głównego miejskiego planisty, rezultaty i korelaty nieefektywnego nadzoru nad przestrzenią miejską zostały już zinwentaryzowane, skategoryzowane i wystawione na widok publiczny, znaczy to, że rozpoczął się proces ich oswajania, ich normalizacji, i że $\mathrm{w}$ związku z tym nie będzie (już) trzeba występować przeciwko nim, nie będzie trzeba ich zwalczać.

Zdarza się zatem, iż społeczne uwidzialnienie zjawiska, które - jak „niewidzialne miasto" - wywoływać może skrajnie różne reakcje: poczynając od szczerej fascynacji jego osobną estetyką i jego potencjałem uwięziawiającym, a kończąc na traktowaniu go jako zbioru nielegalnych aktów samowoli psujących "miejski charakter miasta", skutkuje atmosferą sprzyjającą powstrzymaniom. W przypadku "niewidzialnego miasta” udzielić się ona może zarówno jego "kibicom” (przeświadczonym, o czym była już mowa, że „niewidzialne miasto" nie potrzebuje ich wsparcia), jego twórcom i użytkownikom (przeświadczonym z kolei, że skoro coś zostało uznane za godną uwagi wartość, to jest do przyjęcia, nawet jeśli wcześniej traktowano to coś jako substytut), jak i tym wszystkim, którzy z racji pełnionych przez siebie funkcji odpowiadają za porządek i ład estetyczno-przestrzenny w mieście. Ci ostatni skłonni będą zapewne uznać, iż „rozgłos nadany sprawie" automatycznie rozprasza urzędniczą odpowiedzialność za jej - 
takie bądź inne - załatwienie (czyniąc je zadaniem wszystkich, więc poniekąd niczyim).

Wszystkiego za dużo. Jest oczywiste, że ogrom dzisiejszych baz danych, w tym bazy zdjęć dokumentujących przejawy „niewidzialnego miasta", będący (to także oczywista uwaga) konsekwencją rosnącej łatwości technologicznej, z jaką da się obecnie wytwarzać i dystrybuować rozmaite rodzaje danych (również wizualnych), musi koniec końców działać onieśmielająco i zniechęcająco. Skoro bazy danych są tak przepełnione, skoro na pierwszy, drugi i dziesiąty rzut oka odnieść można wrażenie, iż niczego (bądź niewiele) już im (i w nich) brakuje, że stają się one niemal reprezentacjami 1:1, nieuchronnie przechodzi ochota, by coś jeszcze do nich (od siebie) dorzucić 9 .

Ów ogrom, ów imponujący gigantyzm baz danych działa więc (także) demotywująco. Wynika to z - trafnego skądinąd - przeświadczenia, że osobisty, indywidualny gest polegający na przysłowiowym „dorzuceniu własnej cegiełki" do takiej bądź innej bazy w niczym lub prawie w niczym nie zmienia już jej wartości użytkowej, nie wzbogaca jej o nic nowego, nie skutkuje żadnym - po cichu oczekiwanym - efektem synergii, nie rzuca na zgromadzone zasoby nowego światła, nie prowokuje do ich powtórnego uporządkowania w nowy sposób.

Gigantyzm dzisiejszych baz danych - zwłaszcza tych, które oparte są na formule Web 2.0 - unieruchamia również dlatego, że uzmysławia wątpliwą opłacalność angażowania się $\mathrm{w}$ rolę dostarczyciela darmowego kontentu. Nie chodzi już nawet o to, że osoby dodające rekordy do wielkich baz internetowych mają znikomy wpływ na sposób ich przetwarzania i późniejszego wykorzystania. Chodzi o to, że osoby te, widząc błyskawiczne rozrastanie się zasilanych własnymi materiałami baz, muszą prędzej czy później zacząć podejrzewać, iż albo gatekeeperzy tych baz zadowalają się czymkolwiek (co siłą rzeczy nie może się podobać bardziej wymagającym wobec siebie i wobec innych internautom), albo też ostatecznym celem nie jest tu wcale gromadzenie takich czy innych potencjalnie wartościowych dla społeczeństwa danych, lecz (tylko) wywoływanie ruchu w Sieci. Ten zaś jest oczywiście korzystny dla wszystkich, najbardziej jednak dla tych, którzy umieją zamienić go w żywy pieniądz bądź wykorzystać jako narzędzie władzy ${ }^{10}$.

Wreszcie ogromne rozmiary współczesnych baz danych dobitnie uzmysławiają rosnącą złożoność świata społecznego i jego coraz bardziej emergentny charakter. Ofiarami ich gigantyzmu stają się tym razem ci, którzy

${ }^{9} \mathrm{Na}$ ten sam temat zob. L. Manowich, Jezzyk nowych mediów, Warszawa 2006, s. 333-356.

10 Zob. M. Krajewski, Wtadza horyzontalna. O życiu po śmierci Michaela Jacksona, [w:] Miasto przywództwa, red. M. Staniszewski, Poznań 2010. 
mieli nadzieję, że bogactwo zgromadzonego materiału pozwoli/pomoże im znaleźć zupełnie nowe interpretacje dokumentowanych zjawisk i procesów społecznych. W rzeczywistości dzieje się wszakże dokładnie na odwrót: gigantyzm baz danych pociąga za sobą narastającą bezradność interpretacyjną. Ponownie dobrą ilustracją tego paradoksu może być „niewidzialne miasto". Jeśli dysponujemy setkami, tysiącami przykładów oddolnych inicjatyw, które tworzą miasto i miejskość, lecz czynią to zarazem na swój sposób i w nikłym zazwyczaj powiązaniu z "gabinetowymi" wizjami dobrego, dobrze urządzonego i nowocześnie zarządzanego miasta, to z jednej strony możemy mówić - jako badacze - o sporym szczęściu, jednak z drugiej - te setki i tysiące przykładów w jakimś stopniu nawzajem się znosza, utrudniając lub wręcz uniemożliwiając wszelkie "finalne konkluzje”. Ten sam przejaw „niewidzialnego miasta" może być równie dobrze zinterpretowany jako tymczasowa namiastka jakiegoś lepszego rozwiązania, na które na razie nie ma co liczyć, jak i jako taktyczna subwersja wymierzona przeciwko politycznym i ekonomicznym właścicielom przestrzeni miejskiej. Może być odczytany jako gest zapraszający do szukania nowych form uwięziowienia bądź przeciwnie: jako swoiste votum separatum, które ma sygnalizować chęć poszerzania sfery prywatnej oraz stworzenia i podtrzymywania zupełnie nowych linii demarkacyjnych oddzielających "nowych swoich” od "nowych obcych". Może być uznany za dowód brikolażowej pomysłowości estetycznej lub za świadectwo złego smaku. Koniec końców, najłatwiej i najbezpieczniej powiedzieć, że poszczególne przejawy „niewidzialnego miasta" są najczęściej wieloma rzeczami naraz, że najzwyczajniej nie da się ich $\mathrm{w}$ żaden prosty sposób skategoryzować i że cechuje je permanentna mediacyjność (między prywatnym a publicznym, między odzyskiwanym a traconym, między "ładnym" a "brzydkim”, między pro- a antymiejskością, między tymczasowością a trwałością, między oryginalnością a naśladownictwem itd.) ${ }^{11}$.

Permanentna próba generalna. Wiele baz danych - jak się wydaje - ma skłonność do pozostawania swoistymi magazynami-poczekalniami. Grozi im, że w którymś momencie zmienią się w "cyberrupieciarnie” czy "cyberpawlacze", do których upycha się co popadnie (rzeczy-widoki, z którymi jeszcze nie wiadomo, co zrobić, na których zastosowanie nie ma dotąd pomysłu, lecz których - na wszelki wypadek - nie decydujemy się jeszcze wyrzucić/skasować/zdelejtować). Jakkolwiek trywialnie by to zabrzmiało:

\footnotetext{
11 Więcej na temat dylematów dotyczących interpretacji poszczególnych przejawów "niewidzialnego miasta" oraz na temat jego mediacyjności zob. R. Drozdowski, Miejskie miejsca spotkań - niewidzialne prywatne w niewidzialnym publicznym, [w:] Formy zamieszkiwania. Publiczne i prywatne przestrzenie miasta, red. P. Wołyński, Poznań 2010.
} 
łatwiej gromadzić, zbierać dane, niż je przetwarzać, łatwiej je przetwarzać, niż je interpretować (bo niekoniecznie i nie zawsze musi to być to samo). Łatwiej je interpretować, niż wykorzystywać w jakimś konkretnym celu i w zaplanowany sposób.

Jeśli mam w tej kwestii choć trochę racji, należałoby teraz powiedzieć, że przynajmniej niektóre bazy danych mają tendencję do tego, by w wygodny dla siebie sposób przedstawiać się (jedynie) jako miejsca gromadzenia danych, by trwać - najdłużej jak się da - jako swoiste wersje Beta, które stają się jednak w końcu tylko permanentnymi przymiarkami do jakiegoś następnego, bardziej zaawansowanego pod względem metodologicznym etapu projektu.

Oczywiście, można temu zapobiec, z góry określając, co ma i co powinno się dziać z gromadzonymi danymi. Problem w tym, że każde podpowiadane z poziomu założeń bazy postępowanie $\mathrm{z}$ jej zasobami $\mathrm{w}$ jakimś stopniu wyklucza inne (być może równie dobre lub lepsze) sposoby ich wykorzystania. To, co można by nazwać dyscypliną bazy, może równie dobrze uwiarygadniać ją w oczach jej użytkowników, jak i skutecznie do niej zniechęcać. Postępowanie, które w oczach jednych uchodzić będzie za przemyślaną i dobrze skonstruowaną procedurę porządkującą nie tylko to, kto, czym i na jakich warunkach może zasilać bazę, lecz i to, jaka ma być późniejsza metodologia „obróbki” gromadzonych danych, drudzy skłonni będą uznać za niedopuszczalne "formatowanie wyobraźni”. Zatem i tak źle, i tak niedobrze.

Od kolekcji do bazy danych (i z powrotem). Uporczywe samoredukowanie się baz danych do zbiorów danych oczekujacych na jakieś dalsze decyzje (dotyczące tego, co i jak dalej z nimi robić) jest tym bardziej prawdopodobne, im bardziej wierzymy - słusznie czy nie, to już zupełnie inna sprawa - że dane, którymi dysponujemy, które już zgromadziliśmy i nadal gromadzimy, mają jakąś szczególną wartość, że są w jakiś specjalny sposób cenne. Wówczas szybko narasta pokusa, by zacząć przekształcać bazę danych $\mathrm{w}$ coś w rodzaju kolekcji lub by zaczać myśleć o niej jako o zbiorze informacji, który jest w stanie uratować przed "przypadkowymi” interpretacjami i przed „niewłaściwymi” sposobami użycia dopiero ktoś, kto zachowa się wobec niego jak nowoczesny kurator, to znaczy potraktuje go jako punkt wyjścia do stworzenia jakiejś autorskiej opowieści zamkniętej następnie na przykład $w$ formę wystawy, nieinteraktywnej strony WWW lub albumu.

Kłopot $\mathrm{w}$ tym, że podobne sposoby obchodzenia się z bazami danych likwidują większość pierwotnie wiązanych z nimi nadziei i oczekiwań. Przemienianie baz danych w kolekcje, dokonywanie ich swoistej muzealizacji lub redukowanie ich do roli tworzywa służącego budowaniu mniej 
bądź bardziej arbitralnych narracji chcąc nie chcąc niszczy ich początkowy demokratyzm, pozbawia je możliwości ewoluowania $\mathrm{w}$ nowych kierunkach, eliminuje ich (dosłownie i w przenośni rozumianą) nieobliczalność, czyniąc je projektami coraz bardziej zamkniętymi i zarazem coraz nudniejszymi, bo niemal w całości przewidywalnymi.

Być może postrzeganie współczesnych baz danych jako swoistych kolaboratoriów ${ }^{12}$ lub/i jako demokratycznych forów służących agregowaniu oraz porównywaniu z sobą możliwie wielu punktów widzenia grzeszy naiwnością. Zapewne jeszcze bardziej naiwne wydać się może oczekiwanie, by bazy danych (przynajmniej te obywatelskie, zakładające, że każdy jest w stanie włączyć się $\mathrm{w}$ ich współtworzenie) zaczęły być traktowane jako repozytoria „wiedzy lokalnej”, w rozumieniu pokrewnym do sensu, jaki nadał temu terminowi Clifford Geertz ${ }^{13}$, i by stały się tym samym miejscami służącymi eksponowaniu wartości, przekonań i roszczeń tych wszystkich, którzy czują się wykluczani. Nie zmienia to faktu, że każde działanie, które „domyka" bazę danych (przekształcając ją w kolekcję, podnosząc ją do rangi muzealnego zbioru, podwyższając progi dostępowe do niej, kanalizując kierunki jej dalszego rozwoju itd.), uspokajając jednych (zazwyczaj jej inicjatorów i merytorycznych gospodarzy), częściowo odbiera ją drugim (osobom zainteresowanym wpływaniem na jej kształt, wykorzystywaniem jej "po swojemu”, szukaniem dla niej nowych zastosowań itd.).

\section{TRZY WYMIARY PERFORMATYWNOŚCI BAZ DANYCH}

Chcę na koniec spróbować odpowiedzieć na pytanie, czy można sobie wyobrazić performatywność baz danych trochę inaczej, niż to zapropono-

\footnotetext{
12 Więcej na temat idei kolaboratorium i praktyk kolaboratoryjnych zob. Kolaboratorium. Zmiana i wspótdziałanie, red. M. Frąckowiak, L. Olszewski, M. Rosińska, Poznań 2011. Przywołuję tu "procedurę kolaboratoryjną", która - w największym skrócie - służyć ma urefleksyjnianiu takich bądź innych problemów i szukaniu sposobów ich rozwiązywania z wykorzystaniem możliwie wielu perspektyw poznawczych, możliwie wielu odmian wiedzy (nie tylko eksperckiej, lecz również praktycznej, potocznej, wytwarzanej w toku codziennych praktyk i potwierdzanej $w$ codziennych doświadczeniach), ponieważ jest ona, jak sądzę, bardzo zbieżna z ideą nowoczesnej bazy danych. Przyzwyczajamy się chyba do traktowania baz danych jako miejsc ekstraegalitarnych, i to w potrójnym sensie. Po pierwsze, zakładamy, że są to miejsca otwarte: każdy ma prawo wzbogacać je dostarczanymi przez siebie treściami. Po drugie, uznajemy, że wszystkie punkty widzenia są w takich ekstraegalitarnych bazach równoważne, nie ma "gorszych" i „lepszych" danych. Po trzecie, zakładamy również, że każdy ma dostęp do zasobów i, co więcej, reguły dostępowe są takie same dla wszystkich.

${ }^{13}$ Zob. C. Geertz, Wiedza lokalna. Dalsze eseje z zakresu antropologii interpretatywnej, Kraków 2005
} 
wał Marek Krajewski14? Wydaje się, że tak. Owa inna performatywność baz danych oznaczać może (również) prowokowanie do działań wymierzonych przeciwko nim samym, przeciwko wszystkim najważniejszym wpisanym $\mathrm{w}$ nie założeniom, porządkom, hierarchiom i regułom.

Złe bazy będą to czynić bezwiednie. Będą sprowadzać na siebie coraz to nowe podejrzenia, $\mathrm{w}$ rezultacie których $\mathrm{w}$ szybkim tempie rosnąc będzie grono "sabotażystów", gotowych celowo je zaśmiecać, nieżyczliwie szukać szczelin w ich regulaminach, odgrywać się na ich zarządcach „projektowaniem chaosu" itd. Dobre będą prowokowały do oporu wobec siebie intencjonalnie - licząc na to, że ów opór obnaży ich braki, uchroni je przed skostnieniem i będzie wymuszał na nich dotrzymywanie kroku zmieniającym się oczekiwaniom (zarówno ich współtwórców, jak i tych wszystkich, którzy chcą z nich korzystać i „na nich pracować”).

Dlaczego zaprojektowana prowokacyjność baz danych obliczoną na wywoływanie działań skierowanych przeciwko nim samym skłonny tu jestem uznawać za ich walor, a nawet za przejaw ich instynktu samozachowawczego? Performatywność baz pojęta jako ich zdolność do uruchamiania działań urefleksyjniających (i w konsekwencji: naprawczych, uwięziawiających, innowacyjnych, podporządkowanych zmianom na lepsze) w oczywisty sposób zależy od ich performatywności rozumianej jako zdolność ściągania na siebie uwagi (skutkującej wystarczającą liczbą zarówno dostarczycieli kontentu, jak i jednostek chcących potem coś z tym kontentem zrobic). Owa zdolność ściągania na siebie uwagi jest jednak powiązana - właśnie z możliwością prowadzenia z bazą czegoś w rodzaju gry, do której zachęca sama baza. Ktoś może chcieć $w$ tej grze sprawdzać, czy i w jakim stopniu architektura bazy jest modyfikowalna pod wpływem oddolnych presji, ktoś inny może postanowić „przetestować” bazę pod kątem jej politycznej bezstronności, zaś jeszcze ktoś inny - na przykład pod kątem jej zdolności do pielęgnowania i konserwowania więzi, jakie powstają pomiędzy zaangażowanymi w jej tworzenie jednostkami i instytucjami.

Być może znów grzeszę naiwnością, ale sądzę, że performatywność baz danych rozumiana jako wciąganie $\mathrm{w}$ grę, która koniec końców służy określaniu granic autonomii i sprawstwa wszystkich aktorów zaangażowanych $\mathrm{w}$ ich tworzenie, jest niezbędnym warunkiem społecznej wiarygodności podobnych przedsięwzięć. Bazy danych mają dokumentować rzeczywistość, mają próbować ją porządkować i inspirować do jej nowych odczytań. Jeśli mają również uruchamiać działania, które stawiają sobie za cel przekształcanie porządku zbiorowego, czynienie go lepszym i bardziej satysfakcjonującym, muszą same uwolnić się od pokusy prezentowania siebie jako sztywnych, nienegocjowalnych porządków.

${ }^{14}$ Zob. przywoływany już artykuł M. Krajewskiego Performatywność baz danych... 


\section{BIBLIOGRAFIA}

Drozdowski R., Dziennikarstwo obywatelskie - próba socjologicznego opisu, „Ruch Prawniczy, Ekonomiczny i Socjologiczny" 2008, z. 3.

Drozdowski R., Miejskie miejsca spotkań - niewidzialne prywatne w niewidzialnym publicznym, [w:] Formy zamieszkiwania. Publiczne i prywatne przestrzenie miasta, red. P. Wołyński, Poznań 2010.

Drozdowski R., Krajewski M., Reklama społeczna w Polsce. Grzechy i możliwości, [w:] Akademia Europejska - materiaty szkoleniowe, Bielsko-Biała 1998.

Flusser V., Ku filozofii fotografii, Katowice 2004.

Geertz C., Wiedza lokalna. Dalsze eseje z zakresu antropologii interpretatywnej, Kraków 2005.

Kolaboratorium. Zmiana i wspótdziałanie, red. M. Frąckowiak, L. Olszewski, M. Rosińska, Poznań 2011.

Krajewski M., (Nie)widzialne miasto. Wstęp, [w:] niewidzialne miasto \#1. poznań, Poznań 2007.

Krajewski M., Performatywność baz danych na przykładzie bazy danych wizualnych "Niewidzialne miasto", "Człowiek i Społeczeństwo" 2013, vol. XXXVI, iss. 2.

Krajewski M., Wtadza horyzontalna. O życiu po śmierci Michaela Jacksona, [w:] Miasto przywództwa, red. M. Staniszewski, Poznań 2010.

Larsen J., Z rodzina najlepiej wychodzi się na zdjęciach: performatywność fotografii turystycznej, [w:] Badania wizualne w działaniu. Antologia tekstów, red. M. Frąckowiak, K. Olechnicki, Warszawa 2011.

Manowich L., Jezyk nowych mediów, Warszawa 2006. 